\title{
$\lg \mathrm{D}$
}

National Cancer Institute

\section{Source}

National Cancer Institute. IgD. NCI Thesaurus. Code C566.

An immunog lobulin isotype (subclass). This isotype is expressed on naive B cells along with IgM. Little is known about its physiologic role. 